\title{
LA INSACIABLE CURIOSIDAD INTELECTUAL DE RAMÓN KURI
}

ERNESTO DE LA TORRE VILLAR

Facultad de Filosofia y Letras/UNAM

Ramón Kuri Camacho, La Compañía de Jesús. Imágenes e Ideas, Puebla, Benemérita Universidad Autónoma de Puebla-Plaza y Valdés Editores, 2000, 362 pp.

Muchas y variadas son las inquietudes intelectuales de Ramón Kuri. De recia formación escolástica ha penetrado en la modernidad filosófica sin menoscabo de su ejercicio reflexivo, de su capacidad de comprensión y espíritu creativo. Su capacidad magisterial la enriquecen continuas y abundantes lecturas, ávidas investigaciones en archivos y bibliotecas y un interés justo y mesurado por los sanos placeres: la conversación con los amigos y el gusto por la música.

El dominio que tiene de la "gramática" le familiariza con los escri- tos de los clásicos y de los humanistas que en el medioevo hasta los finales del siglo xviI reflexionaban y escribían en la lengua del Lacio. Esta facultad que lo distingue es la que le permite comprender fiel y claramente el contenido de manuscritos y libros raros que conservan antiguos, valiosos, pero olvidados repositorios en nuestro país. De su manejo y utilización -iqué de datos!, iqué de sugerencias!- ha obtenido Ramón Kuri para reflexionar y disertar sobre temas múltiples.

Desde hace tiempo advertíamos las preocupaciones de Kuri en torno a la influencia del "doctor sutil" en el pensamiento novohispano, y también aparejada la difusión de las ideas suaristas en la Nueva España. Sabíamos de su interés por Palafox y su acción política y también, por sus in- 
clinaciones y aún práctica y ejercicio, del canto gregoriano, en el que lo hemos visto actuar con rigor. Algunos de los intereses los habíamos visto volcados en trabajos persuasivos, en ensayos maduros. Hoy Ramón Kuri nos entrega un volumen formal, parte de esos ensayos enriquecidos, al ser parte integrante de un todo formal que centran y concentran su pensamiento.

La Compañía de Jesús, Imágenes e Ideas recoge valiosas aportaciones en torno de un período que aunque rico ha sido poco trabajado. Centrado en la creación y difusión del pensamiento en la época colonial y más concretamente en el abundante siglo XVII y parte del XVIII, Kuri nos entrega sus reflexiones distribuidas en cuatro nutridos apartados, ligados todos por una finalidad: mostrar la aparición de mentalidades, de ideologías que caracterizan muy bien ese largo período.

En esos grandes grupos de temas, de ideas, Kuri vuelca sus inquietudes. Sucinta pero maciza reflexión en torno de las ideas que fluyen desde el siglo XVI hasta nuestros días y al que denomina como “...periodo de urbanización, de ascenso de la burguesía, consolidación de los estados nacionales, pluralización religiosa, bús- queda de certidumbres, desarrollo capitalista, expansión ultramarina y cientifización del cosmos del hombre", es la que inicia este libro. Esta amplia visión de conjunto la une con el pensamiento y acción de la Compañía de Jesús, principalmente en la Nueva España. Del estudio de su pensamiento y acción deriva la tajante afirmación: "La teología jesuita es un nuevo proyecto de sociedad".

Del análisis de esa acción desprende un apartado referente a la influencia que la doctrina suarista tuvo en la formación de esas ideas, en la acción y en el pensamiento de los miembros de la Compañía en la Nueva España. Pormenorizada atención presta a las lucubraciones de numerosos jesuitas o eclesiásticos influidos por las ideas suarecianas como Antonio Núñez de Miranda, Diego Marín de Alcázar, Pablo Salceda; Matías Blanco; Pedro Cesati y otros, reveladores de un núcleo amplio de filósofos y teólogos influidos por las ideas de Suárez, ideas que conmueven no sólo al mundo de los cultores de la teología, sino también del derecho y de la política.

La segunda parte la consagra Kuri a disertar en torno de algunos principios filosófico-teológicos como el de la Ciencia Condicionada. En torno de 
varios principios realiza el análisis de las ideas predominantes en la época escogida, de sus portadores, de la influencia que tuvieron en la formación de la mentalidad y la acción que permitió el ingreso de la modernidad dentro de un mundo que se transformaba por el impacto de ideologías encubiertas bajo un caudal de vivencias poco estudiadas que se ha dado en llamar el mundo barroco.

La tercera parte o apartado es vasta y variada. Se denomina "Imágenes e ideas. La axiología jesuita. Minus probabilismus y Juan de Palafox y Mendoza". Las inquietudes y problemas de la tierra han atraído también a Ramón Kuri, y no podía faltar el interés por ese intenso periodo en el que la filosofía, la teología y el derecho se imbrican, se oponen, chocan; provocan la agitación de los espíritus, la intervención del Estado; la aplicación de políticas regalistas y de medidas prácticas, de conveniencia, para evitar un enfrentamiento total entre la Iglesia y el Estado. En esta parte, Kuri emite sus ideas tanto en el análisis de las diferencias entre el obispo y la Compañía, en el valor de las argumentaciones entre uno y otra, como también acerca del proceso de exaltación del obispo a los altares que tantos favorecedores como enemigos tuvo. Se indica que la preciosa compilación de textos reunidos en la obra de Gregorio Bartolomé Jaque mate al obispo se indica que ella sólo es parte de la inmensa literatura surgida por la acción de Palafox, representa las reacciones no de los actores directos de la contienda, sino de la presencia de ideologías, de mentalidades que transformaban al mundo en los siglos XVI y XVII, las cuales pugnaban por prevalecer en el pensamiento filosófico, teológico y político.

En este apartado incluye nuestro autor algunas páginas consagradas a la Monita Privata, ese panfleto en el que se concentra la malignidad enfilada contra la Compañía, malignidad que atacó también la acción cultural de los jesuitas, su obra evangelizadora en Paraguay y en las Californias y también sus vastas propiedades que por lo bien trabajadas son codiciadas por una burguesía que desea también los bienes territoriales.

Otros ítems se agrupan en este apartado tercero. Se reitera el análisis del espíritu palafoxiano existente en Puebla, el efecto del extrañamiento de los ignacianos del imperio español, hecho que originó aún en el liberal siglo XIX discusiones muy penetrantes. Como un intermedio necesario entre las agitadas y acres dis- 
cusiones, más políticas que puramente filosóficas, Kuri nos ofrece un musical y magistral apartado sobre el cultivo del canto gregoriano en Puebla.

La cuarta parte, rica en variedad y contenido, nos devuelve al estudio de la acción intelectual de la Compañía, al ocuparse de achaques dirigidos a su acción enseñante, a las preferencias o ausencias de ciertos temas en su tarea de difusión del saber. Se revisan también en el capítulo "Derecho, Iglesia y Estado" los principios esgrimidos por los teólogos y juristas salmantinos para justificar la presencia de España en Indias y se contrastan con las tesis excogitadas por pensadores de otras tendencias y latitudes.

Los últimos capítulos de la cuarta parte están consagrados al análisis reflexivo en torno al pensamiento de personalidades sobresalientes, tales como don Andrés de Arce y Miranda, hasta ayer olvidado y hoy sacado a la luz por obra de investigadores de la universidad poblana. El estudio de una pieza oratoria de este reflexivo miembro del cabildo angelopolitano revela la difusión de sus obras e ideas en el ámbito del mundo católico novohispano.

Como dicho fondo del Cabildo era el más grande fondo de sermonarios coloniales, propuse hace varios años su completa organización y catalogación, pues en los sermones, al igual que en los discursos cívicos del siglo XIX, se encierra una pluralidad de amplias corrientes del pensamiento mexicano. Carlos Herrejón se interesó por los sermones y ha iniciado su exégesis; Kuri analiza varios textos de nuestro poblano predicador y revela la hondura de sus ideas.

De otro pico de oro insigne, igual que el Palavicini del P. Vieyra, que tanta influencia tuvo en la mentalidad religiosa hispanoamericana, pues sus sermones fueron fuente obligada de consulta en nuestros colegios y seminarios, también tenemos un penetrante estudio. Y en este mismo apartado hallamos un capítulo bien tramado que entra en el pensamiento relacionado con las apariciones y el culto guadalupano. El análisis certero, preciso y breve de la obra del teólogo guadalupano, el padre Miguel Sánchez, lleva a Kuri a afirmar que sus aseveraciones son las de un teólogo y que su objeto de conocimiento no tiene pasado ni futuro, porque es y su verdad no puede ser probada, sólo puede ser mostrada. "La imagen de la Virgen María, Madre de Dios, de Guadalupe, describe una necesidad a un ámbito del ser que la satis- 
face". Más adelante, apoyándose en Ortega y Gasset afirmará “... que la sustancia de la historia no son las ideas sino las creencias". También aseverará tras rigurosa argumentación que "...toda la verdad religiosa emana de la fuerza pujante del pueblo, y esa fuerza está cargada de un fuerte sentido nacionalista". Kuri condensa en una frase rotunda ese sentido último cuando nos dice: "el mexicano es guadalupano y el guadalupa- nismo es símbolo de mexicanidad".

No cabe duda que Ramón Kuri, también poblano como Sánchez, ha madurado sus reflexiones en torno de aspectos vitales del pensamiento mexicano y de nuestra historia; ha logrado redondear una obra que bajo el patrocinio de la universidad poblana presentamos ahora a nuestros colegas maestros, estudiantes y público en general invitándolos a entrar en su lectura y en su reflexión. 
